\title{
Human Rights: Historical Retrospection \& Conceptual Foundations
}

\author{
Faheem Iqbal Shayiq \\ B.Sc, M.A (Eng), LL.M, U.G.C-N.E.T Qualified Presently Pursuing Research at Law Faculty, Kashmir \\ University, Hazratbal Srinagar, J\&K India,190006
}

\begin{abstract}
As human civilization grew, a need arose to develop certain institutions \& organizations, the most important \& latest of which was the state itself. Primarily this institution was concerned with administration of Justice \& defence. Now for this administration of justice \& defence, the state needed to empower certain people so as to legitimize their work. However more often than not the power conferred came to be abused proving the dictum right that power corrupts \& absolute power corrupts absolutely. The State instead of being a protector became an oppressor. The dominating philosophy of Positive Law furthered the dictatorship, which came to be practiced by the regimes like the Nazi in Germany. Such regimes thriving on the philosophy that law is what is made, irrespective of its goodness or badness \& completely ignoring the concept of what law 'ought' to be, made things worse for the ruled. In this way self-styled autocratic rules came to be formed \& promulgated, not for the benefit of the governed but the vested interests of the governing.

The failure of these machinations led people to look for an alternative but found no options \& started to look to heavens for help \& this led to the revival of Natural Law Philosophy. As per this philosophy the Natural law being the supreme law wants every positive law to be subservient to the Cosmic order. Rousseau, a Naturalist in his treatise On the Social Contract in 1762, had observed \& very rightly so,

"The man is born free but everywhere he is in chains"

The Natural law philosophy aimed at preservation of peace \& establishment of order solely by relying on morals, ethics \& reasoning. This was an immediate cure to the tyrannical enactments \& draconian laws of the autocrats.

But even the Natural Law failed as well beyond a certain point. The chief argument about its insufficiency was that it was an abstract idea \& at times favored the ruler \& at times the ruled. As a result a need was felt to have some other device to rescue the abuse \& misuse of power by the state. The development gave birth to what we call Human Rights Jurisprudence. The Human Rights Jurisprudence has helped the establishment of legal regimes at the International, National as well as State levels. The need necessitated mankind to make endeavors in this direction so that the sacred humanness is preserved \& protected much to the stability of world order.

Key words: Human Rights, Human Rights Protection, Protection, Natural Law, Individual, Freedom
\end{abstract}

\section{Historical Retrospection}

The expression 'Human Rights' had its origin in International law, appertaining to the development of the status of individual in the International legal system, which was originally confined to the relation between sovereign states, who were regarded as the only persons in International law. For all practical purposes, the genesis of this International aspect of Human Rights is not older than the Second World War. Evolution and crystallization of the concept took a long time. The concept of Human Rights embodying the minimum rights of an individual versus his own state is as old as political philosophy. The Natural law philosophy dominated in the Greece of 530 B.C. The main exponent of this period was Heraclitus, who is also regarded as the founder of Natural Law philosophy. His thought paved the way towards ethical \& political side of speculations. Amongst other important proponents of Natural law philosophy in Greece it is imperative to name Socrates ${ }^{1}$, who was a great enquirer of truth, the 'why' \& 'how' of things \& moral values. His thinking was based on a pragmatic \& scientific outlook. According to him 'Virtue' is knowledge.

The Sophists ${ }^{2}$ dominated Greece for a good period of time as well. Their postulation included insight into the man's goodness -badness \& moral rules. They postulated reasons for the obedience of law. It was here that the theory of state, society \& law came into forefront. Platonic doctrine that 'Justice is harmony of man's inner life \& harmony is the quality of justice \& is achieved by reason \& wisdom over desires' \& the Aristotelian 
postulate that the purpose of State, Community \& Law is to enable man to realize a good life, further helped the cause of human rights ${ }^{3}$.

The Stoics were firm believers of naturalness of the world. They held man to be a part of cosmic order $\&$ was bound to live according to the nature. They believed calamities to be a natural phenomenon \& whatever one got was his destiny. The chief proponent of this period was zeno ${ }^{4}$.

Since every man has an intrinsic character to assert dominance. The pursuance of the exertion of dominance \& superiority over others led to the development of three important institutions viz. Family, slavery $\&$ the State ${ }^{5}$. To secure himself, the man sought to live with fellow human beings instead of being in seclusion. The Family system represented the early forms of group living. Apart from men, women \& children, slaves were added to serve the family. The family was dominated by the elder male member \& the individuals were supposed to surrender their rights. The head was the 'patriarch'. No individual in the family had any vested rights \& whatever rights they possessed came to them as a matter of concession. Similar was the fate of women, who were treated inferior \& merely as subservient for pleasure \& work. As per Sophocles, 'silence is a woman's glory'. She was to reserve her opinions. She was only to serve \& one important duty cast on her was the procuring \& upbringing of the children. This attitude was slowly but steadily transformed by the Greek philosophers who emphasized the dignity of all human beings without the distinction of sex or color.

Around 326 B.C. in India, Kautilya came up with a novel treatise 'Arthashastra' which elaborately enunciated the rules \& duties of king towards his subject alongwith the idea of statecraft.

The Legal Philosophy in this regard was further developed by the Romans in the first century B.C ,With Ulpian \& Paulus as the chief exponents, The concept of 'Jus naturale' i.e the law of nature deriving from the dictates of right reason \& 'Jus gentium' i.e the equal law for both the natives \& foreigners was developed. Whileas there was a special law for the Romans known as 'jus civilis'. In Rome, much the same way in Greek was the concept of 'pater familias'. In Rome only Pater Familias earlier had the freedom. He enjoyed absolute authority called 'patria protestas'. All the earnings of family belonged to him. Rooted in this culture of absolutism, the autocratic governance emerged in Rome. In this backdrop the thinkers played a pivotal role to protect people from oppression through their preachings. ${ }^{6}$

The New Testament based on the conceptual notions of The Holy Bible, in around $1^{\text {st }}$ Century A.D, propagated the Christainite dogmas namely, the love for enemy, righteousness, endurance, love \& importantly humane teachings.

The Human Rights trace their development in India in the 'Smritis', ${ }^{7}$ These are the authoritative books on the Hindu laws preaching morals and duties.

In 571 A.D, the doctrines laid down in The Holy Quran laid great emphasis on the development of rights \& human rights in particular. The Holy Quran is considered as a sacred book containing the verba of Almighty God \& the 'aiyats' revealed upon Prophet Muhammad (PBUH). The postulations include among others the giving of charity (zakaat), mercy \& compassion. ${ }^{8}$

Islam is the religion which takes care of Human Rights in times of both war \& peace. There is a comprehensive code of conduct which is to be followed in an armed conflict. The concept of human rights can be studied by going through the 'Quranic' verses \& the 'Sunnah' of Prophet (PBUH), which emphasize the universal brotherhood without any discrimination on the basis of caste, color, sex status, race \& nationality. Before the advent of Islam the Arab world was plagued by the system of slavery, as was the case in Greece \& Rome. But after the Islamisation of the Arab world this practice became derogatory \& illegal. The Holy Quran laid down that it is a great act of charity to free a slave ${ }^{9}$. Another major violation perpetrated by the Arabs before the advent of Islam was the burying of female child alive, which was forbidden by Islam. Islam further laid stress on the concept of the sacrosanctity of the Right to Life. Under Islamic law one cannot take life of a person without a just cause ${ }^{10}$. The present day concept of right to privacy was laid down in Quran with great emphasis.

"O, ye who believe! Enter not the Houses other than your own until you have asked for permission \& saluted those who are inside; that is the best for you in order ye may heed (what is seemly),"11.

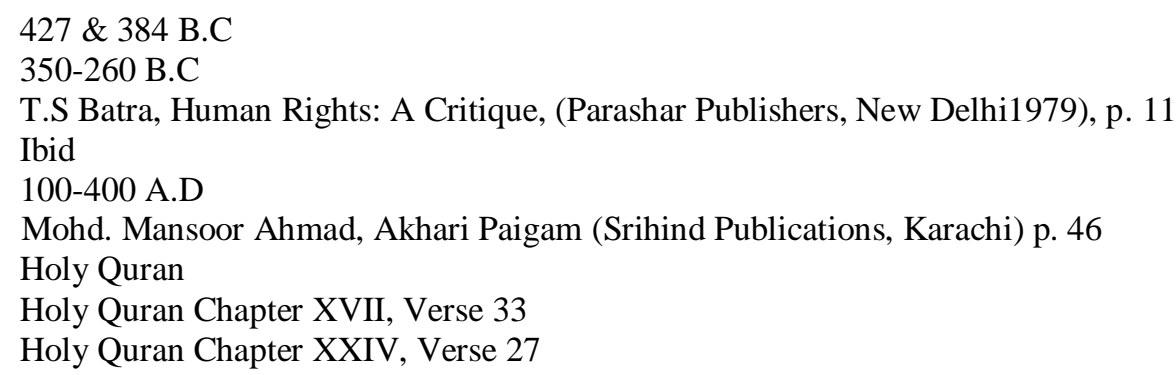


The Right to Equality concept was also explicitly laid down \& taking away the life of a person was banned by the Quranic injunctions.

"If anyone slew a person, it would be as if he slew the whole humanity"12.

The teachings of Quran \& Sunnah was of profound influence which transformed the thinking both in the Muslim as well as the Non-Muslim world.

In 1215 A.D, the Magna Carta was an important event, the first milestone on the road to liberties of the people of England, which is also called the 'Great charter of liberty' The Magna Carta granted by King John of England to the English Barons on June 15, 1215 ensured feudal rights and dues and to guarantee that the King would not encroach upon their privileges. ${ }^{13}$ It assumed a concrete and justiciable shape when these individual rights came to be guaranteed against the state in written constitutions adopted since the Constitution of the America (U.S.A) in 1787, to which the Bill of Rights was formally added in 1791. The effect of incorporation of individual rights in the form of Bills of Rights in a written Constitution is to incorporate human rights into municipal law of a state and to make them legally enforceable by an aggrieved individual against his own state, and to invalidate any state act, legislative or executive, which is found by a court of law to have violated any of the constitutionally guaranteed human rights belonging to the aggrieved individual. These Bills of rights proved to be very important milestones in the development of human rights.

In England Thomas Hobbes emphasized the preservation of peace to be an essential element of Natural law ${ }^{14} \&$ John Locke propounded the theory of natural rights as an instrument of change \& revolution for the establishment of government based on the consent of the governed ${ }^{15}$. Meanwhile in France the passage of Bill of Rights in the 1789 revolution that swept across frontiers introduced the concept of individualism together with radicalism \& rationalism. The Renaissance in Germany, triggered the reformation by applying conscience besides establishment of the individual's right to rebel. Immanuel Kant was an apostle and a forceful proponent of Natural law \& Human Rights. His postulate that an individual's freedom should be consistent with the freedom of others, the theme which he called as the 'categorical imperative'.

In America, another philosopher, and Nobel laureate Martin Luther King, fought against the slavery \& racial discrimination and abuse. In so doing he adopted the path of non-violence which became a success mantra in those days of violence. ${ }^{16}$ The same philosophy was adopted by Gandhi, whose theory of non-violence \& ahimsa, was instrumental in the restoration of basic rights in British ruled India. He fought against slavery, coercion, discrimination and untouchabilty. His contribution in India as well in South Africa have been highly praised by the exponents of Human Rights \& fundamental freedoms ${ }^{17}$ In the American context, the abolition of slavery by Abraham Lincoln, who fought tooth and nail against slavery successfully, established the equality of man. Abraham Lincoln said 'a nation can't be half free \& half slave,18

In 1909, Nelson Mendela fought apartheid tooth \& nail in Africa. He was even sent to jail many a times for his opposition towards the regimes which perpetrated such hate crimes. Aung san su kyi in Myanmar, another Nobel laureate fought for democracy \& restoration of Human rights for the people of her country.

In 1948, after consistent endeavors, the United Nations passed a Declaration, which laid down that all people should have basic rights to live in the society with dignity. ${ }^{19}$ Following the suit, after independence, having been through the worst form of Human Rights abuses, the forefathers of Indian democracy thought it proper to have a detailed provisions about Human Rights to be guaranteed to the individuals, which could be made enforceable. These are laid down in the chapter containing the Fundamental Rights ${ }^{20}$.

The modern concept of Human Rights is just seven decades older. The Atlantic Charter, August 1942, pronounced the four fundamental freedoms.

In 1942 the declaration by 26 members of the United Nations further reaffirmed these principles.

"Faith in fundamental human rights, in the dignity \& worth of human person, in the equal rights of man \& woman, 21

At least it was clear that whether existing in practice or not, these signatories of the Charter were aware that there is some concept by the name of 'Human Rights' \& that the faith in dignity \& worth of human person

12 Tahir Mehmood (Ed). Human Rights in Islam, p. 51

13 Dr. Raj Pal Sharrma, (Human Rights - An Overview", AIR, 2003), Jour 65

14 1588-1679 AD

$15 \quad 1632-1704 \mathrm{AD}$

$16 \quad 1929 \mathrm{AD}$

17 1869-1948AD

18 1809-1864 AD

19 Universal Declaration of Human Rights, 1948 (UNDHR)

20 Chapter III, Indian Constitution, 1950

21 United Nations Charter 1942 
is desirable. ${ }^{22}$ In 1948, the Universal Declaration of Human Rights was adopted by 48 votes. No state voted against it. However eight states viz. the Soviet Union, Poland, Czechoslovakia, Yugoslavia, Ukraine, Byelorussia, South Africa, \& Saudi Arabia, did not vote either way but abstained from voting. The Declaration in its first Article lays emphasis on the dignity of individual.

"All Human beings are born free \& equal in dignity \& rights. They are endowed with reason \& conscience \& should act towards one another in a spirit of brotherhood. ${ }^{, 23}$

After this, two covenants, the Covenant on Civil \& Political Rights \& Covenant on Economic, Social \& Cultural Rights followed. These were approved by the General Assembly on December 16, 1966. All that the covenants are about is that,

a) In the manner of Civil \& Political rights, a compulsory system of reporting to the Human rights Committee as well as an optional system, which would apply only to states which expressly agree to the procedure of fact-finding \& reconciliation, and

b) In the matter of Economic, Social \& Cultural Rights. The system of reports by contracting parties to the Economic \& Social Council be retained \& that on the basis of such reports the council mat adopt recommendations of a general nature without referring to the particular situations or even to particular states. $^{24}$

They came into force in 1976. These further sought to legitimize the Human Rights regime.

In the Europe, as distinct from the world as a whole, the proximity of the scene generated a more marked reaction in favor of Human Rights as a bulwark against the possible repetition of the atrocities of the Nazis \& Fascist rules. The Congress of Europe at the Hague in May 1948, announced its desire for a 'Charter of Human Rights guaranteeing liberty of thought, assembly \& expression ${ }^{25}$ The European Convention was signed on the $4^{\text {th }}$ of November 1950, which provided a Commission \& Court of Human Rights. But the jurisdiction of the court is discretionary so much so for the Commission itself. Thus the guarantees of life \& liberty under this mechanism again becomes more of form than substance as the state cannot be compelled to act in a particular way unless there is acceptance of the procedure $\&$ jurisdiction of the organs.

Much in the same league is the American convention which was signed on November, the $22^{\text {nd }} 1969$ by Chile, Columbia, Costa Rica \& others.

The Indian endeavors were concretized after their long standing demand for freedom from the British yoke materialized. The Indian Constitution makers were keen to draft certain rights as a measure of necessity to give to the people the feel of real liberty, which otherwise would have been merely artificial. The Constituent Assembly convened for this purpose in 1950, inserted provisions in the form of Fundamental Rights \& Directive Principles of State policy. Notwithstanding the fact that now these rights were to be implemented in the law courts, the developments at the International \& National level, culminated in the establishment of a quasijudicial mechanism which would assist \& supplement the normal protection of Human Rights. This led to the enactment of The Protection of Human Rights Act, 1993.

\title{
Conceptual Foundations of Human Rights
}

\section{A) Natural Law Theory}

A staunch follower of Greek Stoic Philosophy, Cicero makes the following consideration of Natural Law,

\begin{abstract}
"True law is right reason in agreement with the nature; it is of universal application, unchanging \& everlasting; it summons to duty by its commands \& averts from wrongdoing by its prohibitions. It is a sin to alter this law. We cannot be freed from its obligations by senate or people. And there will not be different laws at Rome \& at Athens, or different laws now \& in the future, but one eternal \& unchangeable law will be valid for all nations \& all times, \& there will be one master \& ruler, i.e., God, over us all, for he is the author of this law, its promulgator \& enforcing judge. Whoever is fleeing from himself is denying his human nature, \& by reason of this very fact he will suffer the worst penalties, even if he escapes what is commonly considered punishment. ${ }^{26}$
\end{abstract}

22 T.S Batra, Human Rights: A Critique, (Parashar \& Parashar, New Delhi, 1979) p. 41

23 Article1,UNDHR,1948

24 Supra Note 22. pp.43-44

25 Ibid

26 Cicero, Republic III, xxii, p. 33, quoted by Brian Bix, Jurisprudence: Theory \& Context (Sweet \& Maxwell Publication, London) 2006 
The natural law being so co-existent with mankind \& emanating from God Himself, is superior to all other laws. It is binding over all other countries at all the times \& no manmade law will be valid if it is contrary to the law of nature". 27

The Natural Law aspires to deliver absolute justice by consistently appealing to something higher than the positive law for no man-made law can be flawless \& perfect. The Natural law philosophers believe that this Higher law is inherent in every human being \& the society, simply by being a part of the nature. It is not dependent on some artificiality brought about by the 'created', for the 'created' itself owes origin to something higher i.e 'The Creator'. Nature is not just substance but has a relation to the ordering of things. The triology of reason, destiny \& order propounded by 'Heraclitus' became the basis for the Sophistic School of Thought or Greek School of enlightenment. Natural law began with Greeks \& Heraclitus emerged as the first proponent. He stated everything in the universe happens for a reason. A per his philosophy a man cannot rebel against 'Destiny'. However Socrates emphasized the need of moral values. As per him, the justice may be of two kinds, the Natural justice \& the Legal justice. The Natural justice is invariable \& applies uniformly at every place, whileas the Legal justice may vary from system to system. He accords sanctity to Natural Law \& to him the legal rules would be deemed proper, if they resonate with natural justice. However the most prominent authors of Natural law, who are hailed as the founders of western philosophy, although approaching differently, are Plato \& Aristotle.

"If you control the way children play \& the same children play under the same rules \& in the same conditions \& get pleasure from the same toys, you will find that the conventions of adult life too are left in peace without alteration .... change, except in something evil is extremely dangerous., 28

The Natural law philosophy approaches in an apriori fashion, merely by taking everything as for granted \& the same being not susceptible to enquiries, as against the posteriori method, whereby every assumption is analysed on a scientific basis, by an assessment of causes in relation to the subject-matter. The posteriori approach often leads to the critical conclusions, which is not possible under the Natural law.

It is however, to be noted that Natural Law does not always seek to maintain a status-quo. For philosophers, like, Locke, the natural Law can be utilized as an instrument of change. On the other hand, people like Hobbes believe that it is to maintain status-quo in society.

The concept of Natural Law is imbibed in the constitutional schemes, naturally as its acceptance as a 'higher law'. The 'Due Process' \& 'Rule of Law' or most prominently the International law, for example owe origin to the Natural Law. It essentially takes within its ambit the Morality \& Justness of laws, by relating it to the reason of man. It is because of this reason, one's 'will' finds acceptance in a given system of law. From the 'will' of an individual necessarily follows his freedoms. Whenever there was an attempt to suppress the individual's freedom an appeal to natural law was made on the assumption that, beyond crowned heads, there was a system of natural law which embodied reason, justice and universal ethics. Natural rights which are akin to modern human rights were derived from natural law.

The early law of Romans was called 'Jus civile'. Later the Romans developed the legal systems called 'Jus gentium', this was the law of universal application. In the Republican era of Rome, Jus gentium was reinforced by Natural Law as Jus naturael. Jus naturale meant, "The sum of those principles which ought to control human conduct because founded in the very nature of man as a national and social being." ${ }^{, 2}$

According to Romans natural law embodied the elementary principles of justice which were the dictate of right reason. ${ }^{30}$ The natural rights of man were moral rights which every human being, everywhere, at all times, ought to have simply because of the fact that, in contradiction with other beings, he is rational and moral. The natural rights of man, being embodiment of right reason, were "not the particular privilege of citizens of certain state, but something to which every human being, everywhere, was entitled in virtue of the simple fact of being human and rational ${ }^{31}$. Thus, the natural rights were derived from the nature of man for that form part of his intrinsic nature.

During middle ages, St. Thomas Aquinas preached for equality within the framework of a stable society. Teutonic law stressed the fact that law belonged to the community, to the folk, and was thereby the common possession of everyone.

27 Blackstone; Commentaries, Introduction, p.39, quoted by Brian Bix as in Supra Note 40

28 Plato, The Laws, (Penguin Edition 1970), p.797

29 J.L Brierly, The Law of Nations, IX Ed., (Humphrey Waldock, 1963), p.17.

30 Dr.S.K.Kapoor, Human Rights Under International \& Indian Laws, (Central Law Agency, Ald 2005), p.3.

45 M.Cranston, Human Rights Today, 1962, p.9 
Even feudalism, while prescribing duties owed by a vassal to his lord, inspired the idea of 'right' by saying that no more could be demanded of him than was due. ${ }^{32}$ During the period of Reformation and Renaissance, philosophers like Hobbes, Locke and Rousseau propounded social contract theories advocating for individuals inalienable rights for life, liberty and estate, and insisted that the purpose of government was to protect these rights. The doctrines of natural rights have received their fullest expression in the writing of John Locke and other social contract theorists. Locke writes, 'man is by nature endowed with enough freedom to preserve his life and limits his liberty and possession and to be active in rendering the same service to others. For everyman his original liberty has meaning only by reference to this law'. ${ }^{33}$

The list of Natural Rights varied with each exponent as per tending inquisition. Most of the normsetting of natural rights theories contain a priori elements deduced by the norm setter, thus, the rights considered to be natural differ from theorist to theorist, according to the theorist's conception of nature.

Though the heyday of natural rights proved short, the idea of human rights nonetheless endured in one form or another. The abolition of slavery, factory legislation, popular education, trade unionism, the universal suffrage movement, these and other examples of the 19th century reformist impulse afford ample evidence that the idea was not to be extinguished even if its trans-empirical derivation had become a matter of skepticism. But it was not until the rise and fall of Nazi Germany that the idea of rights, Human Rights, came truly into its own.

Human Rights have become a fundamental premise in the International political dialogue. The most important manifestation of Human Rights in the world scene is the belief that a totalitarian regime may no longer victimize its own people with impunity or in virtual silence.

\section{B) Justice Based Approach}

The basic purpose of law is the quest for justice, which is to be administered without passion as "when passion comes at the door, the justice flies out of the window"34 Human Rights are an end of justice, consequently the role of justice is crucial to understanding human rights. Rawls theory is that every individual possesses an inviolability founded on Justice, which even the welfare of society can't override.' In a just society the liberties of everybody are individually settled, which cannot be subjected to bargaining of whatever kind. Now this is possible only by tailoring the system and a properly engineered approach. The modern approach to law can be enunciated by the 'special conception' introduced by Rawls, in which he talks about two principles, viz., The First \& Second principles respectively. As per The first principle, each person is to have a right to the basic liberties consistent with the liberties of others. As per his concept of liberties he included 'political liberty' like the liberty to vote, together with the freedom of speech \& assembly, conscience, property \& the freedom from arbitrary arrest \& seizure. Whileas the Second Principle, emphasize the need to protect the economic \& Social inequalities so that they are to the greatest advantage of the least advantaged besides availing the equality of opportunity in the matters of employment.

As per Rawls these need to be placed in a 'lexical order', so much so that the requirements of the first must be met fully before availing the second. Thus the liberty of person or property be satisfied in priority over the economic efficiency, in case of a conflict between the two.

However if we take the practical argument in a given society riddled with gross inequalities, mere equality in the formalistic sense may be made a mask for injustices. This can illustrated by the example that in case of freedom of expression which both the rich \& poor are entitled to...for example, to propagate their views through newspapers, but a practical constraint which is faced under such circumstances is the fact that the poor may not afford to run newspapers to propagate their views. Thus as per Rawls the special conception is workable in societies enjoying very advanced economies, in which even the worse-off are relatively well-off. And thus justice to be advanced in the realistic sense in other systems must take all the natural \& environmental handicaps into consideration. With respect to Rawlsian second principle which has further complexities. The distributive justice as per him is the fair equalities in the opportunity like in the matters of public employment. However this concept of fairness is easy to preach than practice. For example, a person grown in conditions of discrimination \& deprivation has less opportunity to get into a college than someone from the mainstream with good elementary education. To provide equality of opportunity it is necessary to give some concessional points but that that shall not by \& large compromise the opportunities of others. There may be different approaches to tasking this issue, like a utilitarian or an egalitarian approach.

46 R.W.M Dias, Jurisprudence, (London: Butterworths, 1985), p.78.

33 Polin Raymond, "Rights of Man in Hobbes and Locke", in Raphael (Ed.), Political Theory and Rights of Man, (Bloomington: Indiana Press, 1967), p.20.

34 Allen, Aspects of Justice (Stevens \& Sons, London 1955), p. 34 


\section{C) The Sociological Approach}

The chief \& foremost object of the law is to seek the balancing of interests in a particular society between the individuals which it is composed of. Since in a welfare state law has to be an instrument of Justice. The law to cope with the ever-changing concept of justice has to live up to the aspiration of society. For that matter the law has to be dynamic. Prof C.K Allen observes,

"Experiment involves initiative \& a ceaselessly engineering law suggests picture of a science which is always seeking new instruments, new expedients, for new needs, in short, for good life. The picture is accurate enough for a great deal of what is called social legislation in the modern state, \& this is nowadays a preponderant part of law. It is true that today no enlightened system of law is constant with being merely static: it must also be dynamic, \& a great deal of thought \& knowledge is necessary in order to make it usefully dynamic. ${ }^{, 35}$

The Sociological approach as far as Human Rights are concerned, directs attention to the questions of institutional development aimed at classifying behavioural dimension of law and society, focuses on the problems of public policy and identifies the empirical components of human rights in the context of social process. ${ }^{36}$ Sociological Jurisprudence tends to move away both from the apriori method as well as empiricism. This approach, in so far as it relates to Human Rights, sometimes directs attention to the question of institutional development, sometimes focuses on specific problems of public policy, and sometimes behavioural dimensions of society. A primary contribution of sociological approach is the setting of balances by introducing equilibrium of interests. Dean Rosco Pound has catalogued the interests into the individual, public \& social. The concept of social engineering under his scheme was to consider the prioritization of these interests in a given frame. He wanted to secure all the possible interests with a minimum of friction \& waste.

\section{Islam, Hinduism \& Christianity-}

\section{Religious Approach}

Islam in Arabic means submission to the will of God (Allah), commanding obedience in absoluteness. The homogenous set of norms for all without any favor or discrimination maintains a unison in humanity. Thus introduces the concept of Equality. The teachings of Prophet (PBUH) \& Holy Quran lays down the guidelines, which apart from others emphasizes the basic principle that all men are equal and Islam believes in universal brotherhood. Under the Islamic belief nobody has any superiority over the other. Prophet (PBUH) in crystal clear language has said that Arab was not superior to a Non-Arab nor vice-versa, similarly white has no superiority over a black nor vice-versa, all constitute a brotherhood \& nothing shall avail to a person which belongs to another unless it was given to him by a free will. Thus there is no scope of injustice in Islam. ${ }^{37}$

The importance of Human Rights in Islam lies in the fact that these constitute obligations connected with the Divine order \& as such derive validity from the Creator \& not the Created.

\section{Hinduism} Dharma.

The Hindu philosophy is based on the concept of 'Dharma', \& law is considered as a branch of

According to Manu, 'Dharma' is "what is followed by those learned in Vedas and what is approved by the conscience of the virtuous who are exempt from hatred and inordinate affection". ${ }^{38}$

'Dharma' in simple parlance means the sum total of religious, moral, social and legal duties. There is no distinction between legal duties and moral and religious duties. There is a blending, and inter-working of religious, ethical and legal principles, because law was not separated from religion. Hindu philosophy spoke of Righteousness in terms of law, and law in terms of righteousness. ${ }^{39}$

In the Hindu Philosophy, the starting point is not the individual; it is the whole complex. The individual's duty is to maintain his rights; it is to find one's place in relation to society, to the cosmos, and to the transcendent world. ${ }^{40}$

As Pannikar writes:

"Human rights are not Rights only. They are also duties and both are interdependent.

Humankind has the 'right' to survive only in so far as it performs the duty of maintaining the world (Lokasamagraha). We have the right to eat only in as much as we fulfil the duty

35 C.K Allen, Law in The Making, (Oxford University Press London 9, 1958), p. 38

36 L.D. Naikar, The Law Relating to Human Rights, (Bangalore: Puliani and Puliani, 2004) p.31.

37 Prophet Muhammad (PBUH) Last Sermon, Arafat, 11 A.H (After Hijri) of Islamic Calender

38 Supra Note 36

39 Derret Duncan, Religion and State in India (Faber and Faber, London 1968), p.29

40 Nirveni, Ph.D Thesis, Judicial Enforcement of Human Rights Through PIL, Saurastra, 2005 
of allowing ourselves to be eaten by a hierarchically higher agency. Our right is only a participation in the entire metabolic function of the universe". ${ }^{1}$ brothers.

Rigveda which is regarded as the oldest document declares that all human beings are equal and they are

The Atharvana Veda declared that all human beings have equal right over water and food (natural resources). The Vedas including Upanishads (shrutis) were the primordial source of 'Dharma' which is a compendious term for all human rights and duties....

\section{Christian foundations:}

"Oppressors do all they can to prevent use of the category of justice: they do all they can to cast the situation in terms of better and worse rather than justice and injustice; in terms of good behavior and bad behavior; in terms of benevolence."

Wolterstorff argues that there are two fundamental dimensions to the moral order:

Firstly how we act as an agent and secondly, what is done to us as a recipient/ patient. We are both moral agents who do things and moral patients who have things done to them. What we do has moral significance, and what is done to us has moral significance, and these are not identical. When a moral agent acts in certain morally inappropriate ways they are guilty but they also do wrong to the moral patient. Wolterstorff argues that to do full justice to the moral patients, the victims, to recognize the wrong which has to be done to them, to acknowledge their full worth as human beings, we have to acknowledge that they have rights which have been violated. Failing to recognize this dimension of the moral order risks treating people as objects rather than subjects and this is injustice, or at the very least, quickly leads to injustice.

Christian understandings of human rights are founded on an understanding of human dignity. "Ultimately, for each Christian, it means simply respecting and promoting the human dignity of fellow men and women. It means obeying the greatest commands to love the Lord with all our heart and to love our neighbour as ourselves. ${ }^{44}$

Wolterstorff argues that God has inherent rights, rights which come "bundled" with the fact that God is God. God loves human beings and God's creative love has given human beings worth. From that premise, he maintains: "Once one has said that God has worth, that worth grounds God's right to worship and obedience, and that human beings likewise have worth, it proves impossible not to continue in this line of thought and hold that human beings have rights on account of their worth." 45

"In Christian thought, the foundation of human rights is in the gracious and unmerited love of God. God's love is revealed in Scripture as a love that bestows value on people. So it is important to ground the value of the neighbor not in any imminent quality that he may possess, but as a status conferred by God." ${ }^{, 46}$

41 Pannikar, Is The Notion of Human Rights a Western Concept? 120, Diogenes, 75 (1982), in Henry Steiner and Philip Alston, International Human Rights, In Context, Law Politics, Moral, $2^{\text {nd }}$ ed., (Oxford: Oxford University Press, 2000), p.388

42 Rama Jois, Seeds of Modern Public Law in Ancient Indian Jurisprudence, $2^{\text {nd }}$ ed., (Lucknow: Eastern Book Company, 2000), p.171

43 Wolterstorff, Justice: Rights and Wrongs, p.viii.(Princeton University Press) 2010

44 Wolterstorff, On the Side of the Angels, p.25

45 Supra note 44, p.95

46 Chris Sugden, The Right To Be Human, (Groove Books Ltd. U.K) 1996 p.3. 